> Gi respons på artikler gjennom artiklenes kommentarfelt på tidsskriftet.no.

Innleggene publiseres fortløpende på Tidsskriftets nettside og et utvalg

av innleggene publiseres også i papirutgaven i spalten «Brev til redaktøren».

Redaksjonen forbeholder seg retten til å foreta redaksjonelle endringer.

Forfattere av vitenskapelige artikler har tilsvarsrett, jf. Vancouver-gruppens regler.

\section{Re: Nye rusmidler rett fra nett}

Hege M. Krabseth og medarbeidere har skrevet en interessant og kortfattet oppsummering av de nye psykoaktive stoffene (NPS) (1). Til sammenligning med de mer tradisjonelle rusmidlene er disse stoffene ofte farligere. For norske forhold gjelder dette især parametoksymetamfetamin (PMMA) sammenlignet med metylendioksymetamfetamin (MDMA), bedre kjent som ecstasy. For de hallusinogene stoffene, som vanligvis har lav toksisitet, refererer Krabseth og medarbeidere til et dødsfall som muligens kan relateres til 5-MeO-DALT. De kunne i denne sammenheng også nevnt NBOMe-serien som har ført til dødsfall i USA og Australia $(2,3)$. Begge disse substansene er langt farligere enn tradisjonelle hallusinogene stoffer som LSD og psilocybin.

NPS byr på utfordringer, både når det gjelder toksisitet, påvisning av stoffene og behandling av intoksikasjoner. Det kan være lurt i denne sammenheng å undersøke årsaker til deres fremtredende rolle på markedet.

Som påpekt av Silja Skogstad Tuv og medarbeidere i samme nummer står vi overfor en ny distribusjonsform der kreativ markedsføring kombinert med, blant annet, kjemiske modifikasjoner av eksisterende rusmidler benyttes for å omgå lovgivning og øke salg (4). Dette fører til uante endringer i toksisitet og farepotensial. Fordelen for produsenter og selgere er at stoffene faller midlertidig utenfor narkotikalovgivningen. Straks de blir gjort ulovlige, kommer et nytt incentiv for produsenter for å lage nye stoffer med ukjente virkninger.

Tuv og medarbeidere fremlegger et alternativ til dagens lovgivning der man i stedet utarbeider lister over lovlige legemidler og dermed gjør alle andre stoffer ulovlige. Dette fremstår som en overdreven form for kriminalisering med potensial for uheldige virkninger. Det er samtidig vanskelig å forstå hvorfor de ikke nevner en endring i lovverket omkring de tradisjonelle stoffene. Satt på spissen er en av de viktigste farene ved antatt inntak av MDMA eller LSD at disse i realiteten er PMMA eller 25I-NBOMe, henholdsvis. MDMA eller LSD forårsaker langt mindre skade på samfunn og individ enn alkohol og tobakk (5). Uten denne juridiske stigmatiseringen av LSD og lignende stoffer (6) ville mye av grunnlaget for å lage NPS forsvinne, samtidig som tryggere stoffer med rett lovgivning kunne utkonkurrere NPS på rusmarkedet.

\section{Andreas Wahl Blomkvist}

andreas.wahl@gmail.com

Andreas Wahl Blomkvist (f. 1989) er medisinstudent og redaktør i AEsculap. Ingen oppgitte interessekonflikter.

\section{Litteratur}

1. Krabseth HM, Tuv SS, Strand MC et al. Nye psykoaktive stoffer. Tidsskr Nor Legeforen 2016; 136: 714-7.

2. Daily News. New drug N-bomb hits the street, terrifying parents, troubling cops New York Daily News. 2013 May 6. www.nydailynews.com/news/national/ new-synthetic-hallucinogen-n-bomb-killing-users-cops-article-1.1336327 (11.05.2016).

3. ACMD. 'NBOMe' compounds: A review of the evidence of use and harm. Advisory Council on the Misuse of Drugs. 2013 May 29. https://www.gov.uk/government/ uploads/system/uploads/attachment_data/file/204808/J_TCDO_report_on_ 5-6APB and NBOMe compounds.pdf (11.05.2016)

4. Tuv SS, Krabseth HM, Strand MC et al. Nye rusmidler rett fra nett. Tidsskr Nor Legeforen 2016; 136: 721-3.

5. Nutt DJ, King LA, Phillips LD; Independent Scientific Committee on Drugs. Drug harms in the UK: a multicriteria decision analysis. Lancet 2010; 376: 1558-65.
6. Blomkvist AW, Hårklau H. Hindrer forskning på LSD - et lovende terapeutisk hjelpemiddel. Aftenposten 2015 Jun 16. www.aftenposten.no/meninger/debatt/ Hindrer-forskning-pa-LSD---et-lovende-terapeutisk-hjelpemiddel-8060422.html (11.05.2016).

\section{Re: Bør man kunne tilby keisersnitt ved trisomi 13 og 18 ?}

Jeg ønsker å imøtegå påstanden om at nytten av et eventuelt keisersnitt ikke er dokumentert (1). Som forfatterne selv antyder fører tilbakeholdenhet med sectio også til manglende overvåkning. Fra normale fødsler vet vi at uten overvåkning av fosteret og mulighet for sectio på føtal indikasjon vil flere barn dø under fødselen.

Det er ingen grunn til å anta at dette forholder seg annerledes ved trisomi 13 og trisomi 18. Litteraturen antyder det motsatte (2). Vi vet ikke hvordan det går med dem etterpå, det avhenger av barnets faktiske tilstand (som er vanskelig å bedømme prenatalt) og hvilke tiltak som settes i gang.

\section{Odd Gunnar Paulsen}

odd.gunnar.paulsen@gmail.com

Odd Gunnar Paulsen (f. 1969) er overlege i anestesi ved luftambulanseavdelingen, Oslo universitetssykehus, Ullevål.

Ingen oppgitte interessekonflikter.

\section{Litteratur}

1. Fredheim OM, Hansen TW, Haugen $G$ et al. Bør man kunne tilby keisersnitt ved trisomi 13 og 18? Tidsskr Nor Legeforen 2016; 136: 630-2.

2. Nagase $H$, Ishikawa $H$, Toyoshima K et al. Fetal outcome of trisomy 18 diagnosed after 22 weeks of gestation: Experience of 123 cases at a single perinatal center. Congenit Anom (Kyoto) 2016; 56: 35-40.

\section{O. Fredheim og medarbeidere svarer:}

Vår artikkel om keisersnitt ved trisomi 13 og 18 har avfødt debatt (1). Takk til Kristoffer Brodwall for tilsvar (2). Vi er enige i argumentasjonsrekken angående den lave absolutte risikoen for komplikasjoner ved keisersnitt og ved senere svangerskap for de få som får utført keisersnitt pga. foster med trisomi 13/18. Diskusjonen om komplikasjoner må imidlertid trekkes utover denne sjeldne indikasjonen. Dersom man kun legger vekt på at den absolutte risikoen er lav for hver enkelt kvinne, vil det $\mathrm{i}$ det hele tatt være vanskelig å avvise ønsker om keisersnitt. Man antar at det ved 10-15\% av fødsler er god indikasjon for keisersnitt (3), altså at nytte overstiger risiko og kostnader. Det at vi i Norge ligger i overkant av denne frekvensen skal likevel ikke innebære at man automatisk avviser keisersnitt på nye indikasjoner eller til nye grupper. Både for hver pasientgruppe og hver enkelt pasient må man vurdere om indikasjonen er tilstrekkelig sterk til å oppveie ulempene. For å gi kvinnene mulighet til et informert valg er det av betydning at hun er godt informert om mulige komplikasjoner både ved det aktuelle keisersnittet og ved senere svangerskap. Utfordringen er at vi ikke vet om det er en helsegevinst og hvor stor den eventuelt er for denne pasientgruppen. Da er det vanskelig både for legen og kvinnen å avveie risiko og nytte.

Takk også for innlegget fra Odd Gunnar Paulsen. Vi er enig i at overvåkning ved fødsel vil kunne fange opp fostre som er i risiko for ikke å overleve fødselen. Artikkelen til Nagase og medarbeidere (4) 